\section{Deliberationes tudományos folyóirat}

14. évfolyam 1. szám 2021/1, 137-148.

Kézirat beérkezése: 2021.04.14.

Kézirat befogadása: 2021.08.16.

DOI: 10.54230/Delib.2021.1.137
Deliberationes Scientific Journal

Vol.14; Ed.No. 1/2021, pages:137-148

Paper submitted: 14th April 2021

Paper accepted: 16th August 2021

DOI: 10.54230/Delib.2021.1. 137

\title{
EGYHÁZI SZOCIÁLIS MUNKA HAJDÚDOROGON ${ }^{1}$
}

\author{
Soós Zsolt \\ Debreceni Egyetem, Gyermeknevelési és Gyógypedagógiai Kar
}

\begin{abstract}
Absztrakt
A Hajdúdorogon lefolytatott kutatásunk egy hosszabb, tíz elemből álló kutatássorozat része, amelyben elsősorban az ország kedvezőtlenebb helyzetű régióiban fekvő, kisebb lakosságszámú települések főbb társadalmi jellemzőinek, aktuális társadalmi folyamatainak a feltérképezésére törekszünk. A kutatás során alapvetően a helyi lakosok nézőpontjainak a megismerése és megjelenítése a célunk. A kutatási helyszínek megválasztásában döntő szempont volt, hogy e perifériális régiók kisebb településein meglehetősen kedvezőtlen szocio-demográfiai folyamatok zajlanak, ideértve különösen a települési lakosságszám csökkenését, az idősödést és a hátrányos helyzetü lakosság számarányának a növekedését. E folyamatok - amennyiben nem történnek jelentősebb változások - még a jelenleginél is kedvezőtlenebb jövőképet vetítenek elöre. E kedvezőtlen szocio-demográfiai tendenciák egyértelmüen tetten érhetőek Hajdúdorogon. Ehhez kapcsolódóan a kutatás kiemelt céljának tekintettük a helyi közösségi kapcsolatoknak, ezen belül elsősorban a romák és a nem romák együttélési jellemzőinek, valamint a hátrányos helyzetü romák szociális segítésének a megismerését.
\end{abstract}

Kulcsszavak: hátrányos helyzetü romák, egyházi szociális munka

\section{CHURCH SOCIAL WORK IN HAJDÚDOROG}

\author{
Zsolt Soós \\ Faculty of Education for Children and Special Educational Needs, \\ University of Debrecen
}

\begin{abstract}
Our research conducted in Hajdúdorog is a part of a longer, multiple part research series, in which we will identify the main social features and map the current social pro-

1 A tanulmány elkészítéséhez szükséges kutatómunka az EFOP-3.4.3-16-2016-00021 „A Debreceni Egyetem fejlesztése a felsőfokú oktatás minőségének és hozzáférhetőségének együttes javítása érdekében" címü projekt támogatásával valósult meg.
\end{abstract}


cesses in the less populous settlements of the more deprived regions of the country in particular. Basically, the aim of our research is to understand and present the perspective of the local people. The decisive criterion for the selection of research sites was that the smaller settlements of these peripheral regions are subject to rather unfavourable socio-demographic processes, including in particular the decline in the population, aging and the increase in the share of disadvantaged population. These processes - unless there are significant changes - project an even more unfavourable vision of the future. The adverse socio-demographic processes described above are definitely observable in Hajdúdorog. Related to this, the primary objective of the research was to understand the opportunities, goals and to recognize the local community relations and the characteristics of cohabitation of the Roma and non-Roma population in particular, and social work for disadvantaged Roma.

Keywords: disadvantaged Roma, church social work

\section{BEVEzETÉs}

A publikáció alapját képező kutatómunka egy hosszabb, tíz elemből álló kutatássorozat része, amelyben az ország kedvezőtlenebb helyzetű régióiban fekvő, kisebb lakosságszámú települések főbb társadalmi jellemzőinek, aktuális társadalmi folyamatainak a feltérképezésére törekszünk. A hajdúdorogi kutatásnak az eddig vizsgált településektől (Kisköre, Nagyecsed, Tiszalök) eltérő, s ezáltal fontos tapasztalata, hogy a helyi hátrányos helyzetủ roma családok körében a család- és gyermekjóléti szolgálaton kívül, a görögkatolikus egyház is végez szociális munkát, $\mathrm{s}$ a két segítő beavatkozás szemléletében, alapelveiben és gyakorlatában egymástól jelentősen eltérő modellt követ. A helyi görögkatolikus egyház diakónusának segítő tevékenysége alapvetően igazodik a hátrányos helyzetű családok körében végzett/végzendő szociális munka újra felismert és előtérbe kerülő jelenlétalapú, szükségletorientált, reszponzív szemléletű (Bogács, 2020) életvilág-központú modelljéhez. Ebből következően e tanulmány elsődleges célja, hogy jó gyakorlatként bemutassa a hátrányos helyzetü hajdúdorogi romák körében végzett egyházi segítő tevékenységet.

\section{A CSALÁDOKKAL VÉGZETT SZOCIÁlis MUNKA MODELLJEI}

A hátrányos helyzetű családokkal végzett szociális munkában napjaink Magyarországán állami és önkormányzati intézmények, ideértve különösen a család- és gyermekjóléti szolgálatokat, valamint civil és egyházi szervezetek egyaránt részt vesznek. Az állami szektor intézményei jelentős részében a krízis- és feladatközpontú beavatkozásokat egyaránt magában foglaló, esetmenedzsment szemléletű szociális munkát végeznek (Temesváry, 2018), melyben - különösen a folyamatos vagy ismétlődő krízishelyzetben lévő családok esetében - kiemelt figyelmet kap a gyermekvédelmi aspektus. Az, hogy a halmozottan hátrányos helyzetü, számos ismeret- és képességhiánnyal küzdő családokban a gyermekek legalább az alapvetően elvárható biztonságban nevelkedhessenek, ne 
fordulhasson elő súlyos elhanyagolás vagy bántalmazás. Ebből következően az elsődleges, minimálisan elvárt feladat a családok legalább havi három alkalommal való felkeresése, és annak kontrollja, nem áll-e fenn a gyermek/gyermekek súlyos veszélyeztetése. Ebből következően a család- és gyermekjóléti szolgálatok jelentős részében előtérbe került a kontroll, s ezzel párhuzamosan háttérbe szorult a segítő funkció (Bugarszki, 2014). E modell másik jellemzője a szóbeli tanácsadás prioritása, annak hangsúlyozása, hogy mit kellene tenniük a szülőknek (pl. jobban beosztani a pénzt, nagyobb rendet tartani, többet foglalkozni a gyerekekkel, stabil állást találni, stb.) a helyzetük javítása érdekében. Végül a menedzserizmus írásban rögzíthetö, tényekkel alátámasztható eredményességi elvárásait követve, e modellben kiemelten fontos a tevékenységadminisztráció ${ }^{2}$ (Payne, 2014). Csakhogy ahogy arra Major és mtsai (2011) rámutatnak, e modell alkalmazása halmozottan hátrányos helyzetű családok esetében egy segítői hibán alapul, amelyet a szerzők „civil látásmódnak” neveznek. A segítők ugyanis - akárcsak „az utca embere” - azt feltételezik, hogy minden kliens az életkorának megfelelő érettséggel, elvárható ismeretekkel és képességekkel rendelkezik, és csak az elszánás hiányzott egy jobb, sikeresebb élet kialakítására. Ám mivel e családok számos ismeretés képességhiánnyal küzdenek, a szóbeli „tanácsok” nem jelentenek valós segítséget, nem alkalmasak arra, hogy a „segítettek” helyzetében javulást érjenek el. Így e családok gyakran a szociális munkások asszisztálása mellett süllyednek egyre kilátástalanabb helyzetbe (Bugarszki, 2014), s „örökítik át” azt gyermekeikre is (Váradi, 2015). A napjaink önkormányzati, állami intézményrendszerében szinte evidensnek tartott beavatkozási mód relatíve újkeletű, lépésről-lépésre váltotta fel a másik modellt, az életvilágközpontú segítési gyakorlatot (Bugarszki, 2014). A családsegítést a 2000-es évekig egy a jelenlegitől alapvetően különböző szemléletmód és feladatrendszer ${ }^{3}$ jellemezte: „Magas volt a terepmunka aránya, felkeresték a problémákkal küzdő embereket, akik örömmel fogadták ezt a lehetőséget. [...] Minden szakembert erős motiváció hajtott [...] Napi, heti rendszerességgel tartottak esetmegbeszélést, konzultációt [...] nem volt kötelező adminisztráció, azt mindenki maga dolgozta ki. [...] a családsegítő tevékenység nagyon sikeresen müködött, a kliensek maximálisan elfogadták, s a problémák jelentős részét sikerült is megoldani” (Takács, 2018, 145-146). E gyakorlat megváltozásának az egyik oka, hogy az intézményi és alkalmazotti számában megnövekedett szolgáltatási rendszer működéséhez köthetően, az elmúlt időszak súlyos mulasztásaiból ${ }^{4}$ eredően, számos gyermektragédia történt. Emiatt az Emberi Erőforrások Minisztériuma 2016-

2 Ez a szociális munkában kifejezetten diszfunkcionális hatású, gyakran a tevékenység „leadminisztrálását”, ezáltal „kipipálását”, s az érdemi, tartalmi szociális segítségnyújtás errodálódását eredményezi (Temesváry, 2018; Soós, 2013).

3 A családsegítés intézményrendszerének strukturális átalakulását Rákó (2016) tanulmánya mutatja be részletesen.

4 Például veszélyeztetett, $\mathrm{s}$ emiatt védelembe vett gyermekeket nevelő családok családsegítői meglátogatásának és/vagy a szükséges gyermekvédelmi beavatkozások megtételének a hónapokon keresztüli elmaradása miatt, számos gyermeket éheztetek, kínoztak ezen időszak alatt, melynek következménye e gyermekek súlyos testi és lelki sérülése, több esetben halála lett. 
ban kiegészítette „A személyes gondoskodást nyújtó gyermekjóléti, gyermekvédelmi intézmények, valamint személyek szakmai feladatairól és müködésük feltételeiről szóló 15/1998. (IV. 30.) NM rendeletet", melyben meghatározta azon minimum elvárásokat, amelyeket egy családsegítőnek teljesítenie kell annak érdekében, hogy a segített családban élő gyermekek alapvető biztonsága ne kerüljön veszélybe. Ennek azonban az lett a következménye, hogy a szakemberek jelentős része már csak e minimumtevékenységek ellátását, elsősorban a családok kontrollálását tekinti feladatának, ${ }^{5}$ a tényleges segítői munka pedig háttérbe szorult.

Az életvilág-központú szociális munkában a beavatkozáskor figyelembe veszik, hogy a halmozottan hátrányos helyzetü kliensek sokszor jelentős képesség- és ismerethiányokkal küzdenek, valamint a személyiség érettsége gyakran elmarad az életkori elvárásoktól. Ennek az alapvető oka rendszerint a szülők kedvezőtlen, a szokásos és átlagos ismeretszerzést, személyiségfejlődést gátló gyermekkori szociális háttere. A személyiség érettebbé válásával jellemzően az egyén kötelesség- és felelősségtudata is erősödik, aminek következtében, a saját és családja hosszú távú érdekeit szem előtt tartva, képessé és hajlandóvá válik „a szükségletkielégítés késleltetésére”, például nagyobb erőfeszítést igénylö tevékenységek végzésére is (ideértve a környezet rendben tartását, egy szakmaszerző tanfolyam elvégzését, többműszakos gyári munka vállalását, stb.). Ezért e beavatkozások során az elsődleges cél a személyiség- és a problémamegoldó képesség fejlesztése. Ennek első lépéseként bizalmi kapcsolatot kell kiépíteni a klienssel, amelyhez szükség van a rogersi (1961) alapelvek követésére, vagyis a kliens teljes, feltétel nélküli elfogadására, a kliensekhez való érzelmi odafordulásra. E kliensek a családjukban sok mindent nem tudtak elsajátítani, mely hiátusokat a segítő munka során kell pótolni. Ennek feltétele a segítő és a kliens között kialakuló érzelmi viszonyulás, mely a kliens motiválásának az eszköze is azáltal, hogy a folyamat kezdetén, amikor a személyiség érettségének adott fokán bizonyos értékek még nem interiorizálódtak, a kliens gyakran a segítő kedvéért teszi meg a számára és a családja számára hasznos, ám jelentős erőfeszítést igénylö teendőket (Major, Mészáros, Tatárné Kapus, 2011). A beavatkozás fontos eleme az ismerethiányok pótlásában, egyes képességek fejlesztésében való közvetlen segítségnyújtás. A segítő jelen van a kliens életvilágában, közös tevékenységeken keresztül - például a gyermekkel való közös játék, rendrakás, közösen átgondolt és megvalósított bevásárlás, stb. - ténylegesen hozzásegíti a klienst fontos ismeretek elsajátításához, ezáltal egy sikeresebb élet kialakításához. Ehhez az is szükséges, hogy a jelenlét kellően intenzív legyen, $s$ a segítő a segített család időbeosztásához is rugalmasan alkalmazkodjon (Soós, 2018). E modell hatásos alkalmazásának fontos feltétele, hogy a szociális szakember mellett, a segített családokkal, az azokban felnővő gyermekekkel rendszeres kapcsolatban lévő pedagógusok, egészségügyi és hivatali dolgozók is az adott családok-

5 Ezzel kapcsolatban a kutatásunk során megkérdezett, a 2000-es években még életvilág-központú családsegítést végző munkatárs így fogalmazott: „Szerintem sok olyat dolgot megtettünk, ami nem volt feladatunk" (Soós, 2020, p. 44). 
hoz igazodó, speciális támogatást nyújtsanak. ${ }^{6}$ Ehhez arra is szükség van, hogy e szakemberek is tisztában legyenek a hátrányos helyzetü családok, gyermekek életvilágának sajátosságaival. ${ }^{7}$

A feladatközpontú segítő beavatkozás meglehetősen korlátozott hatásossága napjainkra széles körben ismerté vált. E probléma kezelése, a hátrányos helyzetű családok életkörülményeinek és életlehetőségeinek javítása érdekében az Emberei Erőforrások Minisztériuma és a Bünmeglelözési Tanács felkérésére a Rubeus Egyesület 2017-től, öt helyszínen innovatív család- és gyermekjóléti modellprogramot indított. E programok fontos alapelve a családokat segítő különböző szolgáltatások összehangolt müködtetése (Bányai, 2018; Bogács, 2020), a szükségletalapú és reszponzív szemléletủ beavatkozás, valamint a családok életében való aktív „jelenlét”, az „intenzív családsegítés” és a „kísérés" - ami a családok életének segítői nyomon követését és a szakember széles időintervallumú elérhetőségét egyaránt magába foglalja (Bogács, 2020; Szabó és Tólácziné Varga, 2018). Ezen eredményes modellprogramok kialakítói és megvalósítói úgy vélik, e programok „[...] rendszerszintű adaptálása hozzájárulhat egy új típusú vagy legalábbis új hangsúlyú szükségletközpontú szolgáltatási szakmai attitüd megerösödéséhez" (Bogács, 2020, p. 163).

\section{KUTATÁSI MÓDSZEREK ÉS ESZKözöK}

A kutatásban többféle módszert alkalmaztunk, elemeztük a településre és a térségre vonatkozó társadalomstatisztikai adatokat, valamint a fontosabb dokumentumokat. A kutatás fö módszerének - annak émikus szemléletéhez igazodóan - a szóbeli kikérdezést, eszközként pedig a részben strukturált egyéni interjút választottuk. Előzetes feltérképezés, majd a hólabda módszer segítségével húsz interjút készítettünk el. Törekedtünk arra, hogy a válaszadók szocio-demográfiai szempontból sokszínűek legyenek, s ezáltal a város lehető legtöbb csoportjából csatornázzunk be véleményeket.

\section{A Kutatás helyszíne}

A 8946 lakosnak otthont adó Hajdúdorog (KSH, 2020) Hajdú-Bihar megye északi határán, két nagyobb város, Hadúböszörmény és Hajdúnánás között terül el. A település közszolgáltatásokkal való ellátottsága a lakosságszámhoz viszonyítva kedvező. Az óvodától a középiskoláig helyben elérhetőek a nevelési intézmények, a szociális és gyermekjóléti alapszolgáltatások, ideértve a bölcsődét is, könyvtár, művelődési ház, mozi (heti egy vetítés), továbbá kormányablak is müködik a városban.

A térségben sajátosnak tekinthető történeti fejlődés jelentős hatást gyakorol a tele-

6 A hátrányos helyzetü családokban felnővő gyermekek képességeinek fejlesztésében, ezáltal a hátrányos helyzet „átörökítésének” megtörésében az iskolának, a pedagógusoknak kiemelt szerepe van (Homoki, 2019).

7 Ezért is különösen fontos, hogy ezen ismeretek a pedagógus, az egészségügyi és a közigazgatási képzésekben is helyet és kellő hangsúlyt kapjanak (Soós, 2017). 
pülés mindennapjaira. A török hódoltságot követő időszakban újra benépesült, a XX. század közepéig a környező tanyavilág központjaként is funkcionáló település lakosságszáma 1940-ig közel 12000 föig nőtt, amelyet egy azóta tartó szinte folyamatos csökkenés követett (KSH, 2020). További fontos tényező, hogy a környező településekkel ellentétben a lakosság döntö többsége nem református, hanem görögkatolikus, s e vallás helyi jelentőségét jól mutatja, hogy hazánkban 1913-ban hajdúdorogi székhellyel alapították meg a görögkatolikus föegyházmegyét. Ez a környéken egyedi felekezeti helyzet azonban egyfajta elzárkózást is eredményezett. A családi körbe való bezárkózás napjaikban is jellemző, interjúalanyaink szerint Hajdúdorogon nincs aktív közösségi élet, sőt, még a szomszédok sem tartják egymással a kapcsolatot.

Az, hogy a település egykor központi funkciót töltött be, jelentős vallási eredményeket ért el, viszont az elmúlt évtizedekben a helyi munkalehetőségek száma, s ezzel párhuzamosan a lakosságszám jelentősen csökkent, az idős és a hátrányos helyzetű lakosság, köztük a hátrányos helyzetü romák aránya nőtt, rányomja a bélyegét a helyiek hangulatára, életszemléletére: „A depresszió, a világfájdalom jellemzö” (57 éves nő, könyvtáros).

Roma - nem roma együttélés

Hajdúdorognak az adott térségtől eltérő vallástörténeti fejlődése, vélhetően legalább részben ehhez kapcsolódóan az itt élőknek a környező települések más vallású lakóival szembeni bizalmatlansága, tőlük való elzárkózása, a város határain belül is érvényesül. A helyi romák különbözősége, a többségi lakosságtól részben eltérő életmódja ugyanúgy elzárkózást, bizalmatlanságot, esetenként megvetést eredményez. „Simán kifejezi bárki a nemtetszését a romákkal kapcsolatban, akár trágár módon is" (20 éves férfi, egyetemista). A romák és a nem romák lakóhelyei is elkülönülnek, a helyi romák többsége a település két szegregátumában él, s meglehetősen ritka a romák és a nem romák közötti szomszédság, ugyanis „[...] ha egy cigány család egy utcába beköltözik, onnan elmenekülnek a magyarok" (46 éves férfi, szakmunkás). Interjúalanyaink jelentős része ennek egyik okát a múltból gyökerező elöítéletekben, a másikat pedig abban látja, hogy a roma családok rossz példát mutatnak a nem roma családok gyermekeinek, mivel már a roma gyerekek is dohányoznak, csúnyán beszélnek, agresszívak és túl fiatalon kezdenek szexuális életet élni. Az elkülönülés másik oka a (roma és nem roma) kérdezettek szerint az, hogy maguk a romák is szívesebben élnek saját közösségükben, mint a „magyarok” szomszédságában. Vagyis az elzárkózás kölcsönös. Az elkülönülés másik példája az, hogy a településen egymás mellett működik egy egyházi és egy állami fenntartású általános iskola, $s$ az előbbibe döntő többségében nem roma, míg a másikba napjainkban már nagyobb arányban roma gyermekek járnak. Több interjúalanyunk kiemelte, hogy ez az oktatási elkülönülés nem tudatosan tervezett és irányított folyamat eredményeképpen alakult ki. A családok egy része, ideértve a roma családok többségét, nem teljesíti az egyházi iskola egyházi jellegü követelményrendszerét, a szentségek (elsősorban az egyházi házasság) felvételét, és/vagy az arról való gondoskodást, hogy a gyermekek vegyenek részt a vasárnapi szentmisén. E családok gyermekei így az állami iskolában tanulnak. Ugyanakkor interjúalanyaink szerint a nem romák egy része éppen 
amiatt teljesíti e követelményrendszert, hogy a gyermek abba az iskolába kerülhessen, amelybe kis létszámban járnak roma gyerekek. Vagyis, ha nem is célzott és tudatos szegregációról van szó, a két iskola adott módon való működése lehetőséget ad a romák és a nem romák részleges oktatási elkülönülésére. A gyermekkortól induló, és az életet végig kísérő elkülönülés, $\mathrm{s}$ az egymás nem ismeréséből kialakuló kölcsönös elöítélet (Forgas, 2007) jelenléte érzékelhető a városban. Ugyanakkor interjúalanyaink többsége ennek kapcsán úgy vélekedik, helyben kevéssé okoz problémát a „cigánykérdés”, mivel a romák és a nem romák között alig van interakció, így konfliktusok sincsenek „[...] csak elélnek egymás mellett" (19 éves férfi, egyetemista). A romák és a nem romák viszonyáról, a helyiek felelősségéről az aktív telepi segítői munkát végző diakónus ${ }^{8}$ az alábbiakat fogalmazta meg: „A magyarok általánosságban eltürik őket. Nem foglalkoznak velük, nem jellemzö, hogy segítenék az én munkámat, és egyáltalán az, hogy belássák, hogy ez egy nagyon nagy kérdés itt Dorog számára, meg ahol roma lakosság van. [...] S ami mondjuk itt Dorogon kimaradt, teljesen elmaradt, az iskolán kívüli társadalmi munka, vagy mindegy, hogy minek nevezzük, szociális munkának."

\section{A ROMÁK ÉLETKÖRÜLMÉNYEI}

A fenti elkülönülés súlyos következménye, hogy a roma szegregátumokban élők a mindennapi élet eredményes szervezése, az életkörülmények jobbá tétele kapcsán kevéssé látnak megfelelő mintát, követendő példát, $s$ bár vannak segítő beavatkozások, ám kellő mértékü, s ezáltal kellően hatásos segítségre csak kevéssé számíthatnak. Így e családok jelentős része beleragad a mélyszegénység, $s$ az ezzel együtt járó halmozott hátrányok generációról-generációra hagyományozódó állapotába.

A romák életkörülményeiről, mindennapjairól az alábbiakat mondták el interjúalanyaink:

Kimentem a telepre [...] ott '60-as évekbeli állapotokat találtam, nagyon leszegényedett és nagyon magukra hagyott embereket [...] Az általános képlet az volt, hogy csak ágy van, nincsen szekrény, nincs hol tisztálkodni, ebből adódott a helyzet, hogy ezt akkor valahogy pótolni kell. [...] Vannak olyan lakások, ahol 25-en élnek [...] minden helyiségben többen laknak" (diakónus).

„Sok a probléma. Sok ember él egy házban, ahol nincs fürdőszoba. [...] Problémák vannak az óvodai, iskolai hiányzással, nem akarják engedni oviba a gyereket. Elhanyagolás van, meg higiénés problémák. Jellemző a gyerekek nem megfelelő táplálása, a nagy kosz. Kiemelt terület gyermekvédelmi szempontból” (22 éves nö, szociálpedagógus hallgató).

8 Aki e munkát jelentős részben egyedül látja el, ami a beavatkozás hatásosságának is szükösebb keretet szab. 


\section{A CSALÁD- ÉS GYERMEKJÓLÉTI SZOLGÁLTATÁSBAN VÉGZETT SEGÍTŐI MUNKA}

A szolgáltatásban végzett szociális munka napjainkban - eltérően a szolgáltatásmüködés kezdeti éveitől - a megkérdezett családsegítő (49 éves nő) összegzése alapján, esetmenedzsment szemléletű. A beavatkozások alapvetően gyermekvédelmi központúak, $\mathrm{s}$ a végzett tevékenységek kontroll hangsúlyosak. Ennek kapcsán diakónus interjúalanyunk az alábbi tapasztalatait fogalmazta meg: „Úgy tünt, amikor elkezdtem ezt a munkát, hogy cserbenhagyták itt a roma lakosságot [...] Nekem nagyon az tünik még most is, hogy akinek a feladata lenne ez hivatalból, amit számon kérnek tölük azt teljesítik, a többlet pedig lemarad, elmarad. Ebböl az egész történetböl az emberi egymással foglalkozás szinte alig tapasztalható. Ha mindig jogszabályok szerint megyünk, hogy nézzük, hogy egy-egy családba mi a probléma, jó, hát ez is segitség, hogy felhívjuk rá a figyelmét, hogy ki kell takarítani, meg legyen egy ruhásszekrényed, de hogy ettöl többet nem segítenek [...] a helyi illetékes személyek, én ezzel szembesültem. És akkor eldöntöttem, hogy én tényleg beleállok ebbe a munkába."

\section{A RoMÁK HELYZETÉT JAVÍTÓ EGYHÁZI SEGÍTő BEAVATKOZÁSOK}

A helyi görögkatolikus egyház szociális segítő tevékenysége - amelyben a szociális munka rövid és távlati céljai (Soós, 2018) egyaránt megjelennek - több pillérre épül:

1, A családok, a családtagok lelki megerősítése, abban való segítségnyújtás, hogy legyen hitük az életben, abban, hogy képesek jobb életet élni, jobban nevelni a gyermekeiket.

2, Az alapvető fizikai szükségletek kielégítésében való segítségnyújtás, ehhez kapcsolódóan adományozási tevékenység végzése és a lakás- és életkörülmények jobbá tételének segítése.

3, Az életkörülményeket és a mindennapokat hosszabb távon jobbá, eredményesebbé tevő programok megvalósítása, melyek egyben a segítettek személyiségfejlődését, személyiségük érettebbé válását is előmozdítják (roma földprogram; munkahelykeresésben való segítségnyújtás).

4, A helyi roma és nem roma közösség közötti kapcsolatok erősítése, a roma lakosság helyi közösségbe, különösen a helyi vallási közösségbe való integrálása.

\section{A SEGÍTŐ BEAVATKOZÁSOK TARTALMA, MÓDJA, FOLYAMATA}

A helyi görögkatolikus egyházhoz 2013-ban egy diakónus csatlakozott, akinek a roma pasztoráció a fő feladata. Munkájának kiemelt eleme a szociális segítségnyújtás, amely követi a szociális munka etikai és szakmai alapelveit (Soós, 2018). E tevékenység eredményességéhez elengedhetetlen, hogy a helyi parókus is prioritásnak tekintse az életvilág-központú szociális segítő modellben megfogalmazott célok elérését, vagyis a segített családok tekintetében egy sikeresebb mindennapi élet kialakításának előmozdítását (Sárkány, 2011). 
A diakónus első feladatának azt tartotta, hogy megismerkedjen a romákkal, s hogy elfogadják öt nem roma emberként segítőnek. A helyi roma - nem roma viszony miatt, amiatt, ahogy a romák ezt megélték, megélik, ez nem volt könnyü. „Ök nyilván úgy itélik meg, hogy el vannak nyomva, szegregálva vannak [...] mindenhonnan csak a rosszat kapják. Ennek is megvan az oka [...] nem mindegy, hogy egy városon belül milyen vezetés van, milyen a családsegitö munkája, mert ők velük találkoznak, a polgármesteri hivatal, meg a családsegítö, meg a pap bácsi, maximum az iskola. Ha innen mindenhonnan negatív visszajelzéseket, negatív erőket kapnak, akkor milyen is lehet a véleménye." A kölcsönös megismerést, elfogadást és a hatásos segítő beavatkozást szolgálja, hogy a diakónus mindennap kijár a szegregátumokba.

A romák nyomorúságos helyzete miatt, az első feladatok közé tartozott a családok adományokkal való segítése, amely tevékenységet azóta is végzik. Ugyanakkor e családok lelki erejének, ezáltal e roma emberek személyiségének a fejlesztését tűzték ki elsődleges, az életük jobbá válását eredményezö célnak. „Legyen hite az életben, önmagában is bizzon [...] hogy a gyermekemet felneveljem [...] Ha ebben nem segitjük öket, ha ezt elhagyjuk, akkor nincs felzárkózás" (diakónus).

A helyi parókus (52 éves férfi) az egyházi szociális munkában az adományok nyújtása mellett, kiemelten fontosnak tartja a roma földprogramot, melynek keretében vetőmagot biztosítanak a szegregátumokban élő családoknak, felszántják a kertjeiket. Ennek eredményeképpen több család ma már igyekszik, gondozza a kiskertjét, élelmiszert termel magának. A segítő beavatkozások által elindított szemléletváltás is elősegítette azt, hogy napjainkra a kizárólag támogatásokból élő helyi romák csoportja egyre kisebb, sokan alkalmi és idénymunkákat, egyre többen pedig állandó munkát tudnak vállalni. Mindez jelentősen javítja a családok életkörülményeit, $s$ változtatja kedvező irányba a családtagok mindennapi tevékenységét.

A helyi egyház kiemelt tevékenysége a „[...] tanítás, a nevelés, a lelki gondozás [...] hogy érezzék, hogy ide tartoznak" (parókus). Ennek eredményei már láthatók: a romák egyre nagyobb számban vesznek részt szentmiséken, igényelnek keresztelést vagy egyházi temetést. Úgy tapasztalják, sikerült szorosabb kapcsolatot kiépíteni a helyi romák többségével. Ezáltal az egyház jelentős szerepet vállal a roma és a nem roma közösség kapcsolatának, különösen a romák egyházközösségi integrációjának erősítésében. Ennek egyik példája, hogy templombúcsú idején már a roma hívek is részt vesznek a közös ebéden és ünneplésben. Bár az első évben voltak problémák, de már nincsenek, és a nem roma lakosság is megtapasztalta, hogy a romák is tudnak szépen ünnepelni.

Ezen eredmények elérése elképzelhetetlen egy intenzív, jelentős energiabefektetést és érzelmi odafordulást igénylő, a kliensek életvilágához igazodó szociális munka nélkül. A mindennapi segítségnyújtás példájaként a diakónus az alábbi esetet ismertette: „Amikor adódik egy szituáció, egy helyzet, hogy azt gyorsan meg kell oldani [...] Odatelefonált este 9-kor tavaly, hogy „„Pap bácsi nagyon nagy baj van [...] csorog befele a plafonon a víz [...] jöjjön ki, nézze meg." [...] Kimentünk [...] tényleg csorgott [...] nem volt katasztrófahelyzet [...] Másnap ezt nagyon gyorsan megoldottuk. Találtam egy roma embert, akinek 
jó kézügyessége van, és szereztem hozzá palát, lécet, meg ami kellett, és egy-két nap alatt megoldottuk a problémát."

A parókus és a diakónus egyaránt kiemelte, hogy a segítőmunka továbbfejlesztését tervezik, távlati céljuk egy roma közösségi ház kialakítása, melynek müködtetésével a hitélet és a közösség tovább erősíthető. Ez pedig azért is kiemeltem fontos, mert: „Kell egy biztos talaj, amin el tudnak indulni. Ezt a talajt szeretnénk a lábuk alá adni azzal a hittel, amibe lehet kapaszkodni" (Parókus).

\title{
BEFEJEZÉs
}

Hajdúdorog példája rámutat arra, hogy az évezredes hagyománnyal rendelkező egyházi szociális segítés, a szociális munka innovatív gyakorlatát, s a keresztény tanításokkal egyező reszponzív szemléletét követve, jelentős eredményeket érhet el a hátrányos helyzetü családok segítésében. A helyi görögkatolikus egyház tevékenységében a hitéleti munka és a szociális segítés egymást erősítő hatásúnak bizonyul. Az egyház az egyéni segítés mellett, figyelmet fordít a helyi közösség, a közösségi kapcsolatok megerősítésére is. E folyamat eredménye a helyi keresztény közösség újra-erösödése, s a romáknak e közösségbe való befogadása. Ehhez elengedhetetlen volt, hogy az egyház munkatársai képesek legyenek mozgósítani e keresztény közösségben rejlő erőforrásokat, amelyekre így vélhetően a jövőben a segítő munka során is fokozottabban lehet építeni.

Kapcsolattartó szerző:

Soós Zsolt

Debreceni Egyetem

Gyermeknevelési

és Gyógypedagógiai Kar

4220 Hajdúböszörmény

Désány István u. 1-9

soos.zs@ped.unideb.hu

\author{
Corresponding author:
Zsolt Soós \\ Corresponding author:
Zsolt Soós \\ Faculty of Education for Children \\ and Special Educational Needs, \\ University of Debrecen \\ Désány István str. 1-9 \\ 4220 Hajdúböszörmény, Hungary \\ soos.zs@ped.unideb.hu
}




\section{IRODALOMJEGYZÉK}

Bányai, E. (2018). Szempontok és javaslatok az intenzív családmegtartó szolgáltatások gyermekjóléti munkába való bevezetéséhez. In Rácz, A. (szerk.). Szülöi kompetenciafejlesztést célzó modellprogramok a gyermekjóléti szolgáltatások tárházában. (6-21). Rubeus Egyesület.

Bogács, E. (2020). Jelenlétalapú reszponzív gyermekjólét. In. Rácz, A. A szülőség támogatásának új útjai a gyermekvédelemben. (158-164). Rubeus Egyesület.

Bugarszki, Zs. (2014). A magyarországi szociális munka válsága. Esély, 25 (3), 64-73.

Emberi Erőforrások Minisztériuma. A személyes gondoskodást nyújtó gyermekjóléti, gyermekvédelmi intézmények, valamint személyek szakmai feladatairól és működésük feltételeiről, 15/1998. (IV. 30.) NM rendelet \$. 12-18 (2016).

Forgas, J. P. (2007). A társas érintkezés pszichológiája. Kairos.

Homoki, A. (2019). A gyermekvédelmi szükségletorientáció az óvodai, iskolai segítésben. Deliberationes, 12 (1), 43-70.

Major, Zs. B., Mészáros, K., Tatárné Kapus, É. (2011). Az eltéphetetlen gyökér. IRTÓ Bt; PMJVÖ Esztergár Lajos Családsegítő és Gyermekjóléti Szolgálata.

ogers, C. (1961). On Becoming a Person: A Therapist's View of Psychotherapy. Constable.

Payne, M. (2014). Modern Social Work Theory. (4th Edition). Palgrave Macmillan. https://doi.org/10.1007/978-1-137-40603-3

Rákó, E. (2016). Változó családsegítés: gyermekjóléti szolgáltatások a család és gyermekjóléti szolgálaton át a család és gyermekjóléti központig. Szociálpedagógia, 3-4, 5-12.

Sárkány, P. (2011). Szociálpedagógiai elméletek. Jel Kiadó.

Soós, Zs. (2013). Állami szolgáltatásvásárlás a szociális szolgáltatási rendszerben: A támogató szolgálatok működésének tapasztalatai Győr-Moson-Sopron megyében. Esély, 24 (1) 3-38.

Soós, Zs. (2017). Szociális ismeretek oktatása a pedagógus BA képzésekben. Szociálpedagógia, 5 (3-4), 24-38.

Soós, Zs. (2018). Szociális esetmunka. Debreceni Egyetemi Kiadó.

Soós, Zs. (2020). Hajdúdorog kortárs társadalmi folyamatai. Különleges Bánásmód, 6 (3), 33-50. https://doi.org/10.18458/KB.2020.3.33

Szabó, A., Tolácziné Varga Zs. (2018). Intenzíven a pincétől a padlásig. In Rácz, A. (szerk.). Szülöi kompetenciafejlesztést célzó modellprogramok a gyermekjóléti szolgáltatások tárházában. (97-153). Rubeus Egyesület.

Takács, I. (2018). A családsegítő szolgálatok tevékenysége a kezdetektől napjainkig. In Kovács, I. és Lakner, Z. L. (szerk.). Rendszer és váltás. A Szociális Törvény első 25 éve. (141-157). L’Harmattan. 
Temesváry, Zs. (2018). A szociális munka és a szociálpedagógia modern elméletei. L'Harmattan.

Területi Statisztika: Népesség, népmozgalom. Központi Statisztikai Hivatal (2020).

Váradi, M. M. (2015). Szegénység, projektek, közpolitikák. Tér és Társadalom, 29 (1), 69-96. https://doi.org/10.17649/TET.29.1.2678 